\title{
Antiplasmodial activity of methanol leaf extract of Citrus aurantifolia (Christm) Swingle
}

\author{
Ette Ettebong $^{1 *}$, Peace Ubulom ${ }^{2}$, Aniekeme Etuk ${ }^{3}$ \\ ${ }^{1}$ Department of Clinical Pharmacology and Therapeutics, Faculty of Clinical Sciences, University of Uyo, Nigeria \\ ${ }^{2}$ Department of Animal and Environmental Biology, Faculty of Science, University of Uyo, Nigeria \\ ${ }^{3}$ Department of Pharmaceutics and Pharmaceutical Technology, Faculty of Pharmacy, University of Uyo, Nigeria
}

\section{A R T I C L E I N F O}

Article Type:

Original Article

Article History:

Received: 7 October 2018

Accepted: 6 July 2019

Keywords:

Antiplasmodial effect

Medicinal plant

Citrus aurantifolia

Chemosupression

\begin{abstract}
A B S T R A C T
Introduction: Citrus aurantifolia (Christm) is a plant used for the treatment of various ailments including malaria. This study aimed to evaluate the in vivo antiplasmodial efficacy of methanol leaf extract of C. aurantifolia in Swiss albino mice.

Methods: The median lethal dose $\left(\mathrm{LD}_{50}\right)$ was determined by intraperitoneal administration of different doses of the extract (100-4000 mg/kg) to 6 groups of 3 mice each and the animals were observed for 24 hours for physical signs of toxicity. To evaluate the antiplasmodial activity of the extract, three models were used: suppressive, curative and repository. Doses of the extract used were 320, 640 and $960 \mathrm{mg} / \mathrm{kg} / \mathrm{d}$ in mice, with Chloroquine $(5 \mathrm{mg} / \mathrm{kg} / \mathrm{d})$ as standard drug. Pyrimethamine $(1.2 \mathrm{mg} / \mathrm{kg} / \mathrm{d})$ was used as the standard drug for the repository test and distilled water $(10 \mathrm{~mL} / \mathrm{kg} / \mathrm{d})$ as control in all models.

Results: In all models, the low dose $(320 \mathrm{mg} / \mathrm{kg})$ of the extract produced the highest chemosuppressive effects in all models $(P<0.001)$. Mice treated with extract lived longer than those in the control group $(P<0.001)$. Phytochemical screening revealed the presence of alkaloids, flavonoids, saponins, tannins and cardiac glycosides and the $\mathrm{LD}_{50}$ of $3280 \mathrm{mg} / \mathrm{kg} \pm$ 0.01 shows that the extract has low toxicity.

Conclusion: The result of this study shows that C. aurantifolia has antiplasmodial properties which support its use in ethnomedicine in the treatment of malaria.
\end{abstract}

Implication for health policy/practice/research/medical education:

The methanolic leaf extract of Citrus aurantifolia is a low toxic plant with antiplasmodial activity which can be exploited as a potential source of new antimalarial drug to combat malaria.

Please cite this paper as: Ettebong E, Ubulom P, Etuk A. Antiplasmodial activity of methanol leaf extract of Citrus aurantifolia (Christm) Swingle. J Herbmed Pharmacol. 2019;8(4):274-280. doi: 10.15171/jhp.2019.40.

\section{Introduction}

Malaria is a disease of the blood that is caused by the protozoan microparasite of the genus Plasmodium, which affects red blood cells (1). About 156 species of Plasmodium that infect many types of animals have been identified, however, only Plasmodium falciparum, Plasmodium vivax, Plasmodium ovale, Plasmodium malariae and Plasmodium knowlesi are known to infect humans (1).

The disease is as old as humanity itself (2). Numerically, the most important of the life-threatening protozoan diseases is malaria, which is responsible for at least 750000 deaths a year (3). There were 212 million new cases of malaria worldwide in 2015 (range 148-304 million). In 2015, there were an estimated 429000 malaria deaths (range 235000-639000) worldwide. Most of these deaths occurred in the African region (92\%), followed by the South-East Asia Region (6\%) and the Eastern Mediterranean Region (2\%). Between 2010 and 2015, malaria incidence rates (new malaria cases) fell by $21 \%$ globally and in the African region. During this same period, malaria mortality rates fell by an estimate of $29 \%$ globally and by $31 \%$ in the African Region (4).

Treatment of malaria requires the use of antimalarial drugs. Recently, there was a major breakthrough by Chinese researchers in the discovery of antimalaria agent Artemisinin (Quinghao), an endoperoxide sesquiterpene lactone as the active component of Artemisia annua, an herbal remedy used in Chinese folk medicine for over 2000 years (5). This antimalarial drug was developed due to the problem of resistance to older forms of antimalarial 
drugs like chloroquine. Although clinically relevant Artemisinin resistance has not been demonstrated, it is likely to occur since artemisinin resistance has been obtained in laboratory models (5).

Majority of populations in many tropical countries depend on traditional medical remedies using herbs (6). There is increased dependence on herbal remedy as a result of high cost of artemisinin-based combination therapy (ACT) to populations in third world countries because of the high number of peasants and low-income earners who are at most affected by the disease (7).

Citrus aurantifolia in its natural state is widely used in West Africa, particularly in Nigeria, where it is employed in herbal medicine to treat several illnesses. Crushed leaves are applied to forehead to treat headache and it is squeezed near the nostril for irritant inhalation to treat nausea and resuscitate fainting individuals (8). A decoction of the flower is believed to help induce sleep for those with insomnia (8). The fruit juice has been found useful to treat irritation, diarrhoea and swelling due to mosquito bites. It is sometimes mixed with oil and used as vermifuge and also incorporated into weight management diet (9). Decoction of roots is used to treat dysentery, diarrhea, colic, gonorrhea and fever (10). The extracts of the fruit peels, leaves and the essential oil of the leaves of $C$. aurantifolia have been shown to possess anticholinesterase and butyrylcholinesterase activity (11). Similarly, the hydroalcoholic extract of C. aurantifolia in the form of tincture has been found to have anti-platelet aggregation activity (12). Extracts of the root have been found to have antibacterial and antimycobacterial $(13,14)$, as well as antifungal and antiaflatoxigenic activities (15). C. aurantifolia has been shown to inhibit colon cancer (16) and has antioxidant (17), immune-modulatory (18), antiobesity (19), antifertility activities (20). In southwest Nigeria, the roots, bark, stem twigs, leaves and fruits are used in the treatment of malaria (21).

This study was aimed at investigating the in vivo antiplasmodial activity of the leaf extract of C. aurantifolia.

\section{Materials and Methods}

Collection and identification of plant material

Fresh leaves of C. aurantifolia were collected from the Faculty of Pharmacy Medicinal Plants Farm, University of Uyo in October 2017.

\section{Plant extraction}

The leaves of $C$. aurantifolia were washed; air-dried and pulverized using a mortar and pestle. The powdered plant material was weighed ( $26.97 \mathrm{~g}$ ) and cold macerated for 72 hours at room temperature using methanol. The methanol extract that was obtained by filtration was concentrated in vacuo at $40^{\circ} \mathrm{C}$ using a rotary evaporator. The dried extract obtained was weighed and stored in a refrigerator prior to further studies.
Phytochemical screening

The qualitative phytochemical screening was carried out on the methanol extract using standard methods (22).

Animals

Both male and female animals (Swiss albino mice) weighing 15-27 kg used for these experiments were obtained from the Animal House of the Faculty of Pharmacy, University of Uyo. The animals were kept in well ventilated standard cages, fed with growers pellet feed and water ad libitum.

Parasite and preparation of inoculum

A chloroquine-sensitive strain of Plasmodium berghei berghei (NK-65) was obtained from Nigeria Institute for Medical Research (NIMR), Lagos and was maintained by sub passage in mice. The parasitized blood donor with high parasitaemia was obtained by first anaesthetizing the mouse with chloroform, and through cardiac puncture blood was collected using sterile syringe. The percentage parasitaemia was determined by counting the number of parasitized red blood cells against the total number of red blood cells. The inoculum was prepared by diluting 2 $\mathrm{mL}$ of the parasitized blood with $10 \mathrm{~mL}$ of sterile normal saline, to obtain the final inoculum of $0.2 \mathrm{~mL}\left(1.0 \times 10^{7}\right)$, which is the standard inoculum for the infection of a single mouse (23).

\section{Acute toxicological study}

Acute toxicological study was carried out to determine the median lethal dose $\left(\mathrm{LD}_{50}\right)$ and the safety profile of the methanol leaf extract of $C$. aurantifolia using the modified method of Miller and Tainter as described by Nwafor et al (24) and Jigam et al (25). This involved intraperitoneal administration of different doses of extract (100-4000 $\mathrm{mg} / \mathrm{kg}$ ) to 6 groups of 3 mice each. The animals were observed for the first 2 hours and then at the 6th and 24 hours period for manifestation of physical signs of toxicity such as writhing, decreased motor activity, decreased body/limb tone, decreased respiration and death. The number of deceased mice was counted in each group and percentage mortality calculated. The calculated percentage mortalities were transformed into probit values and were plotted against log-doses and then the dose corresponding to probit 5 , i.e., $50 \%$ was recorded as the $\mathrm{LD}_{50}$ value. The standard error (SE) of the $\mathrm{LD}_{50}$ value was calculated using the formula:

$$
\text { SE of } L D_{50}=\frac{(\log \text { probit } 6-\log \text { probit } 4)}{\sqrt{2 N}}
$$

Where, $\mathrm{N}=$ number of animals in each group.

Determination of antiplasmodial activities

Suppressive activity

Suppressive effect of the extract on early infection (4 - 
day test) was determined. The mice were each inoculated on the first day (day 0), intraperitoneally with $0.2 \mathrm{ml}$ of infected blood containing about $1 \times 10^{7} \mathrm{P}$. berghei parasitized erythrocytes. The animals were then randomly divided into five groups of 6 animals each. On day one $\left(\mathrm{D}_{0}\right) 0.2 \mathrm{ml}$ of infected blood containing P. berghei was administered intraperitoneally to all mice. Groups 1-3 received 320, 640, and $960 \mathrm{mg} / \mathrm{kg} / \mathrm{d}$ of the leaf extract respectively. Group 4 received $5 \mathrm{mg} / \mathrm{kg} / \mathrm{d}$ of chloroquine (standard drug) which served as the positive control, while Group 5 served as the negative control group and received $10 \mathrm{~mL} / \mathrm{kg}$ of distilled water. The administration of extract and drug was continued daily for 4 days $\left(\mathrm{D}_{0}-\right.$ $\mathrm{D}_{3}$ ), between $8.00 \mathrm{AM}$ and $9.00 \mathrm{AM}$. On the fifth day $\left(\mathrm{D}_{4}\right)$, thin blood films were made on microscopic slides using blood obtained from the tip of the tail of each mouse in the model. The slides were stained with Leishman's stain and examined under the $100 \mathrm{x}$ oil immersion microscope to determine the effect of the extract (26). The World Health Organization (WHO) method of counting parasites was adopted. This was to determine the presence of malaria parasites. Here, two tally counters were used to count parasites and white blood corpuscles (WBCs) with one counter used for the WBCs and the other for the parasites. Counting was commenced at the top most part of the film by looking for a field with a good number of WBCs. After all the parasites and WBCs in one field were counted, it was moved to the next field until 200 WBCs were counted then the counting stopped. Care was taken not to overlap fields. The parasite density was calculated using the formula (27):

$$
\text { Parasite density }=\frac{\text { Parasite count }}{W B C \text { count }} \times 8000
$$

\section{Repository/prophylactic activity}

The method of Ettebong et al (28) was also employed to evaluate the prophylactic activity of the extract. Groups 1-3 were administered with 320, 640 and $960 \mathrm{mg} / \mathrm{kg}$ of the extract orally. Group 4 animals served as positive control and were administered with $1.2 \mathrm{mg} / \mathrm{kg} / \mathrm{d}$ of pyrimethamine. Group 5 animals served as negative control and received $10 \mathrm{~mL} / \mathrm{kg}$ of distilled water. All the groups were treated for three consecutive days (D0-D2) and on day 4 (D3), the mice were intraperitoneally injected with $0.2 \mathrm{~mL}$ of infected blood that contained $1 \times 10^{7} \mathrm{P}$. berghei parasitized red blood cells (RBCs). The parasite density was assessed using thin films obtained from tail blood of each mouse, 72 hours after parasite inoculation. The earlier method of counting parasites described for suppressive model was also adopted for this model.

\section{Curative activity}

The earlier method described by Ettebong et al, (28) and Adu-Gyasi et al, (26) was used. A quantity of $0.2 \mathrm{ml}$ of blood containing $P$. berghei berghei parasitized blood was administered intraperitoneally to the mice on the first day (D0) and left for 72 hours for parasitaemia to be established. The mice were randomized into 5 groups of 6 animals each. Groups 1-3 received 320, 640 and $960 \mathrm{mg} /$ $\mathrm{kg} / \mathrm{d}$ of the leaf extract respectively. Group 4 received 5 $\mathrm{mg} / \mathrm{kg} / \mathrm{d}$ of the chloroquine (Standard drug) and served as the positive control. Group 5 received $10 \mathrm{~mL} / \mathrm{kg}$ of distilled water and served as the negative control. All the drugs were administered to the animals once daily for five days. Tail blood sample from each mouse was collected daily for 5 days and stained with Leishman's stain. Thereafter, thin films were prepared and used to determine the parasite density. The earlier method of counting parasites described for suppressive model was also adopted for this model.

The mean survival time (MST) of each group was determined over a period of 30 days $\left(\mathrm{D}_{0}-\mathrm{D}_{29}\right)$.

MST $=\frac{\text { Number of days survived }}{\text { Total of Number of days }} \times 100$

Data analysis

Results were expressed as multiple comparisons of mean \pm standard error of the mean (SEM). Significance was determined using one-way analysis of variance (ANOVA). A probability level of $5 \%$ or less was taken as significant.

\section{Results}

Phytochemical constituents of methanol leaf extract of Citrus aurantifolia

The phytochemical screening of methanol leaf extract of C. aurantifolia revealed the presence of saponins, alkaloids, tannins, flavonoids and cardiac glycosides.

Acute toxicity study

The mean lethal dose $\left(\mathrm{LD}_{50}\right)$ was determined to be 3280 $\pm 0.01 \mathrm{mg} / \mathrm{kg}$.

\section{Antiplasmodial activities \\ Suppressive test}

In the suppressive test, the methanol leaf extract of $C$. aurantifolia showed a reduction in parasite density/ $\mu \mathrm{L} /$ blood in mice treated with low and middle doses of extract and these reductions were statistically significant $(P<0.001)$ compared to control but less than that of standard drug. The low dose gave $75.66 \%$ chemosuppression. However, parasite density was found to increase in the high dose of extract compared to control. This depicts that the extract has a partial agonistic effect (Table 1).

\section{Repository test}

In the repository test, there were reductions in parasite densities in animals treated with low and middle doses of extract. These reductions were statistically significant $(P<0.001)$ but more pronounced in animals treated with low dose of the extract. The percentage chemosuppression 
Table 1. The suppressive antiplasmodial activity of methanol leaf extract of Citrus aurantifolia in mice (4 days test).

\begin{tabular}{llll}
\hline Drug/Extract & Dose $(\mathrm{mg} / \mathrm{kg})$ & Parasite $(\mu \mathrm{L} / \mathrm{blood})$ & Density/\% Chemosuppression \\
\hline Distilled water & $10 \mathrm{~mL}$ & $269792.00 \pm 4.67$ & $75.65^{*}$ \\
Extract & 320 & $65680.00 \pm 1.49^{*}$ & $33.19^{*}$ \\
& 640 & $180.256 .67 \pm 2.70^{*}$ & $17.71^{*}$ \\
Chloroquine & 960 & $317575.67 \pm 4.71^{*}$ & $99.67^{*}$ \\
\hline
\end{tabular}

Values are expressed as mean $\pm \mathrm{SEM} ;{ }^{*} P<0.001$ compared to control, $\mathrm{n}=6$.

for low and middle doses were $99.83 \%$ and $97.75 \%$ respectively and these were comparable to that of the standard drug, Pyrimethamine (Table 2).

\section{Curative test}

In the curative test it was observed that there was a reduction in parasite density in mice treated with the extract from the $4^{\text {th }}$ to the $7^{\text {th }}$ day. Low doses of the extract had more curative effects than the middle and high doses. These reductions were statistically significant $(P<0.001)$ compared to control. The low dose of the extract exhibited more curative effect than the standard drug chloroquine (Table 3).

\section{Mean survival time}

The result showed that mice treated with the extract lived longer (16.35-27.33 days) than those in the control group (9.01 days) $(P<0.001)$. Survival times of mice treated with low doses of extract compared favorably with those of standard drug, chloroquine (Table 4).

\section{Discussion}

The preliminary phytochemical screening of the methanol leaf extract of $C$. aurantifolia showed the presence of alkaloids, saponins, flavonoids, cardiac glycosides and tannins. Alkaloids are one of the major classes of compounds possessing antimalarial activity, and one of the oldest and important antimalarial drugs, quinine belongs to these compounds (29). Saponins, flavonoids and tannins have been suggested to act as primary antioxidant or free radicals scavengers that can counteract the oxidative damage induced by the malaria parasite (29). However, the lack of oxidizing action in some plant does not rule out antiplasmodial activity since they may be active through other biochemical mechanisms (30). The presence of alkaloids in C. aurantifolia extract might have contributed to antiplasmodial activity exhibited by the plant extract. Also the presence of saponins, flavonoids and tannins in the methanol leaf extract of C. aurantifolia justify the antiplasmodial activity exhibited by the plant extract.

The median lethal dose $\left(\mathrm{LD}_{50}\right)$ of the extract in mice was calculated to be $3280 \mathrm{mg} / \mathrm{kg} \pm 0.01$, which is slightly toxic according to the toxicologic testing methods by Loomis and Hayes (31). This indicated that the extract is not very toxic and somewhat safe for oral use.

Standard antimalarial drugs like chloroquine, halofantrine, mefloquine and artemisinin have been tested using animal models. The in vivo antiplasmodial activity of the methanol leaf extract of $C$. aurantifolia was investigated by evaluating the chemosuppression during the early infection (suppressive test), established infection

Table 2. The repository antiplasmodial activity of methanol leaf extract of Citrus aurantifolia in mice

\begin{tabular}{llll}
\hline Drug/Extract & Dose $(\mathrm{mg} / \mathrm{kg})$ & Parasite $(\mu \mathrm{L} / \mathrm{blood})$ & Density/\% Chemosuppression \\
\hline Distilled water & $10 \mathrm{~mL}$ & $52961.54 \pm 4.55$ & 99.83 \\
Extract & 320 & $91.82 \pm 0.00^{*}$ & 97.75 \\
& 640 & $1189.41 \pm 2.00^{*}$ & -597.08 \\
& 960 & $369187.35 \pm 5.30^{*}$ & 100 \\
\hline
\end{tabular}

Values are expressed as mean $\pm \mathrm{SEM} ;{ }^{*} P<0.001$ compared to control, $\mathrm{n}=6$.

Table 3. The curative antiplasmodial activity of methanol leaf extract of Citrus aurantifolia in mice

\begin{tabular}{|c|c|c|c|c|c|c|}
\hline \multirow{2}{*}{ Drug/Extract } & \multirow{2}{*}{ Dose $(\mathrm{mg} / \mathrm{kg})$} & \multicolumn{5}{|c|}{ Parasite Densities $/ \mu \mathrm{L}$ of blood } \\
\hline & & Day 3 & Day 4 & Day 5 & Day 6 & Day 7 \\
\hline Distilled water & $10 \mathrm{ml}$ & $149883.67 \pm 4.40$ & $138680.15 \pm 2.10$ & $101869.82 \pm 1.67$ & $79950.18 \pm 1.45$ & $80630.32 \pm 1.70$ \\
\hline \multirow[t]{3}{*}{ Extract } & 320 & $149109.00 \pm 4.06^{*}$ & $92906.66 \pm 1.21^{*}$ & $27862.70 \pm 1.33^{*}$ & $851.67 \pm 0.95^{*}$ & $287.33 \pm 0.63^{*}$ \\
\hline & 640 & $150849.33 \pm 4.45^{*}$ & $130037.40 \pm 1.40^{*}$ & $51198.80 \pm 0.90^{*}$ & $23671.60 \pm 0.65^{*}$ & $4235.50 \pm 1.35^{*}$ \\
\hline & 960 & $148345.45 \pm 3.70^{*}$ & $132540.20 \pm 1.35^{*}$ & $57280.06 \pm 0.85^{*}$ & $42495.03 \pm 1.95^{*}$ & $8506.00 \pm 1.22 *$ \\
\hline Chloroquine & 5.0 & $149210.35 \pm 4.40 *$ & $20899.33 \pm 1.00 *$ & $16520.50 \pm 0.66^{*}$ & $4528.65 \pm 0.97^{*}$ & $1117.00 \pm 1.25^{*}$ \\
\hline
\end{tabular}

Values are expressed as mean $\pm \mathrm{SEM} ;{ }^{*} P<0.001$ compared to control, $\mathrm{n}=6$. 
Table 4. Mean survival time (MST) of mice receiving various doses of methanol leaf extract of Citrus aurantifolia

\begin{tabular}{lcc}
\hline Drug/Extract & Dose $(\mathrm{mg} / \mathrm{kg})$ & MST $($ days $)$ \\
\hline Distilled water & $10 \mathrm{~mL}$ & $9.01 \pm 0.25$ \\
Extract & 320 & $27.33 \pm 0.55^{*}$ \\
& 640 & $23.33 \pm 0.20^{*}$ \\
& 960 & $16.35 \pm 0.66^{*}$ \\
Chloroquine & 5 & $27.15 \pm 0.53^{*}$ \\
\hline
\end{tabular}

Values are expressed as mean $\pm \mathrm{SEM} ;{ }^{*} P<0.001$ compared to control, $\mathrm{n}=6$.

(curative test), the repository test and the mean survival time.

In the suppressive test, the methanol leaf extract of C. aurantifolia showed a reduction in parasite density/ $\mu \mathrm{L} /$ blood in mice treated with low and middle doses of extract. However, parasite density was found to increase in the high dose of extract compared to control group. This depicts that the extract has a partial agonistic activity. Similar findings were also reported for the aqueous root extract of Berberis aristata (32).

In the curative test it was observed that there was a reduction in parasite density in mice treated with the extract from the $4^{\text {th }}$ to the $7^{\text {th }}$ day. Low doses $(320 \mathrm{mg} /$ $\mathrm{kg}$ ) of the extract had more curative effects than the middle and high doses of the extract. C. aurantifolia has antioxidant properties (18) and it is known that such properties may become prominent in low doses than in high doses. For instance, vitamin $\mathrm{C}$ is a naturally occurring organic compound and a potent antioxidant preventing oxidative damage to lipids and other macromolecules. It can also exhibit bimodal activity as a pro-oxidant at a higher concentration (33). It is certainly well established that vitamin $\mathrm{C}$ can serve as a pro-oxidant through formation of ascorbyl radical (34). This result may therefore be associated with the pro-oxidant property of C. aurantifolia. The low dose $(320 \mathrm{mg} / \mathrm{kg})$ of the extract exhibited more curative effect than the standard drug chloroquine. The methanol leaf extract of C. aurantifolia displayed chemosuppression in a dose-independent manner. As expected, $320 \mathrm{mg} / \mathrm{kg}$ body weight of the plant extract prolonged the mean survival time of the study mice indicating that it suppressed $P$. berghei and reduced the overall pathologic effect of the parasite on the mice. Similar findings were also reported for extracts of Lecaniodiscus cupanioides and Echinops hoehnelii $(35,36)$.

In the repository test, there were reductions in parasite densities in animals treated with low and middle doses of extract. The percentage chemosuppression for low and middle doses were comparable to that of the standard drug, pyrimethamine.

In the mean survival time, the result showed that mice treated with the extract lived longer than those in the control group. Survival times of mice treated with low doses of extract compared favorably with those of the standard drug, chloroquine.

Chloroquine has shown a greater chemosuppresive activity than the extract of $C$. aurantifolia except for the curative test where the low dose $(320 \mathrm{mg} / \mathrm{kg})$ of the extract showed a greater chemosuppressive activity than chloroquine. This implies that the low dose of methanol leaf extract of $C$. aurantifolia has an advantage over chloroquine since it is effective and with no known resistance as compared to chloroquine.

\section{Conclusion}

The results of this study show that the leaf extract of C. aurantifolia possesses significant antiplasmodial activity in vivo, which is dose independent. Preliminary phytochemical screening of the extract showed the presence of alkaloids, saponins, flavonoids, cardiac glycosides and tannins. The antiplasmodial activities of this plant may be ascribed to these constituents. This study has established a rationale for the ethnomedicinal use of the plants in the treatment of malaria in Nigeria.

\section{Acknowledgements}

Authors are grateful to Mr. Aniefiok and Mrs Ukeme, both staff of the Department of Clinical Pharmacology and Therapeutics, Faculty of Clinical Sciences, University of Uyo, for their technical assistance.

\section{Authors' contributions}

EE and UP designed the study and interpreted the results. EE did statistical analysis of the results. EE, UE and AL did the experiments and assisted in the writing of the manuscript. All authors read and confirmed the last edition of the manuscript and confirmed it for publication.

\section{Conflict of interests}

Authors declare that no competing interest exists.

\section{Ethical considerations}

Approval for the use of animals in the study was obtained from the Animal Ethics Committee of the Faculty of Pharmacy, University of Uyo (UUP41).

\section{Funding/Support}

This research was carried out with personal funds from the authors.

\section{References}

1. Centers for Disease Control and Prevention Malaria. 2017. Available from: http://www.cdc.gov/dpdx/ malaria/. Accessed August 21, 2019

2. Mehta D, Desai N. Laboratory diagnosis of malaria. Various method and its comparison. Natl J Integr Res Med. 2013;4(3):138-43.

3. World Health Organization Fact sheet. World Malaria report. Available from http://www.who.int/malaria/ media/world-malaria-report-2017/en/. 2017. Accessed 
August 21, 2019.

4. World Health Organization (WHO). Malaria. WHO; 2013. http://www.who.int/mediacentre/factsheets/fs094/ en/. 2013. Accessed October 9, 2013.

5. World Health Organization (WHO). Malaria. International travel and health. WHO; 2016. http:// www.who.int/ith/diseases/malaria/en/. 2016. Accessed August 24, 2016.

6. Meshnick SR. Artemisinin: mechanisms of action, resistance and toxicity. Int J Parasitol. 2002;32(13):165560 .

7. World Health Organization (WHO). World Malaria Report. Geneva, Switzerland: WHO Press, WHO; 2012.

8. Idongesit NJ, Eteng MU, Akpanabiatu MI, Uwah AF, Otitoju O, Akpanyung EO. Effect of Hippocratea africana root bark extract on some biochemical indices of male and female albino Wistar rats. J Pharmacogn Phytother. 2013;5(4):72-6. doi: 10.5897/JPP12.0276.

9. Khan IA, Abourashed EA. Leung's Encyclopedia of Common Natural Ingredients: Used in Food, Drugs and Cosmetics. New Jersey: John Wiley and Sons Publication; 2010:422-3

10. Akhtar SS. Evaluation of Cardiovascular Effects of Citrus aurantifolia (Linn.) Fruit. Social Science Research Network: Retrieved from: http://ssrn.com/ abstract=2279447. 2013. Retrieved August 21, 2019.

11. Kunow MA. Maya medicine: Traditional healing in Yucatan. New Mexico: University of New Mexico Press; 2003:117.

12. Chaiyana $\mathrm{W}$, Okonogi S. Inhibition of cholinesterase by essential oil from food plant. Phytomedicine. 2012;19(89):836-9. doi: 10.1016/j.phymed.2012.03.010.

13. Piccinelli AL, Garcia Mesa M, Armenteros DM, Alfonso MA, Arevalo AC, Campone L, et al. HPLC-PDA-MS and NMR characterization of C-glycosyl flavones in a hydroalcoholic extract of Citrus aurantifolia leaves with antiplatelet activity. J Agric Food Chem. 2008;56(5):157481. doi: 10.1021/jf073485k.

14. Aibinu I, Adenipekun T, Adelowotan T, Ogunsanya T, Odugbemi T. Evaluation of the antimicrobial properties of different parts of Citrus aurantifolia (lime fruit) as used locally. Afr J Tradit Complement Altern Med. 2006;4(2):185-90.

15. Sandoval-Montemayor NE, Garcia A, Elizondo-Trevino E, Garza-Gonzalez E, Alvarez L, del Rayo CamachoCorona M. Chemical composition of hexane extract of Citrus aurantifolia and anti-Mycobacterium tuberculosis activity of some of its constituents. Molecules. 2012;17(9):11173-84. doi: 10.3390/molecules170911173.

16. Jazet Dongmo PM, Tatsadjieu LN, Tchinda Sonwa E, Kuate J, Amvam Zollo PH, Menut C. Essential oils of Citrus aurantifolia from Cameroon and their antifungal activity against Phaeoramularia angolensis. Afr J Agric Res. 2009;4(4):354-8.

17. Jayaprakasha GK, Mandadi KK, Poulose SM, Jadegoud Y, Nagana Gowda GA, Patil BS. Novel triterpenoid from Citrus aurantium L. possesses chemopreventive properties against human colon cancer cells. Bioorg Med Chem. 2008;16(11):5939-51. doi: 10.1016/j. bmc.2008.04.063.
18. Loizzo MR, Tundis R, Bonesi M, Menichini F, De Luca D, Colica C, et al. Evaluation of Citrus aurantifolia peel and leaves extracts for their chemical composition, antioxidant and anti-cholinesterase activities. J Sci Food Agric. 2012;92(15):2960-7. doi: 10.1002/jsfa.5708.

19. Pourhossein Z, Qotbi AA, Seidavi A, Laudadio V, Centoducati G, Tufarelli V. Effect of different levels of dietary sweet orange (Citrus sinensis) peel extract on humoral immune system responses in broiler chickens. Anim Sci J. 2015;86(1):105-10. doi: 10.1111/asj.12250.

20. Asnaashari S, Delazar A, Habibi B, Vasfi R, Nahar L, Hamedeyazdan S, et al. Essential oil from Citrus aurantifolia prevents ketotifen-induced weight-gain in mice. Phytother Res. 2010;24(12):1893-7. doi: 10.1002/ ptr.3227.

21. Bakare AA, Bassey RB, Okoko II, Sanyaolu AO, Ashamu AE, Ademola AO. Effect of lime juice (Citrus aurantifolia) on histomorphological alterations of the ovaries and uterus of cyclic Sprague-Dawley rats. Eur J Sci Res. 2012;67(4):607-16.

22. Gul R, Jan SU, Faridullah S, Sherani S, Jahan N. Preliminary phytochemical screening, quantitative analysis of alkaloids, and antioxidant activity of crude plant extracts from Ephedra intermedia indigenous to Balochistan. ScientificWorldJournal. 2017;2017:5873648. doi: 10.1155/2017/5873648.

23. Okokon JE, Ubulom PM, Udokpoh AE. Antiplasmodial activity of Setaria megaphylla. Phytother Res. 2007;21(4):366-8. doi: 10.1002/ptr.2059.

24. Nwafor PA, Ettebong EO, Umoh EE, Essien GE. Antiinflammatory and analgesic effects of ethanolic extracts of Carpolobia ltea leaves in mice. Niger J Exp Appl Biol. 2008;9(2):125-32.

25. Jigam AA, Abdulrazaq UT, Egbuta MN. In-vivo antimalarial and toxicological evaluation of Chrozophora senegalensis A. Juss (euphorbiaceae) extracts. J Appl Pharm Sci. 2011;1(10):90-4.

26. Adu-Gyasi D, Asante KP, Newton S, Amoako S, Dosoo D, Ankrah L, et al. Malaria parasite density estimated with white blood cells count reference value agrees with density estimated with absolute in children less than 5 years in central ghana. Malar Res Treat. 2015;2015:923674. doi: 10.1155/2015/923674.

27. Dharani N, Rukunga G, Yenesew A, Mbora A, Mwaura L, Dawson I, et al. Common antimalarial trees and shrubs of East Africa. The World Agroforestry Centre; 2010.

28. Ettebong EO, Edwin UP, Edet EC, Samuel EU, Ezekiel $\mathrm{AO}$, Dornu TV. In vivo antiplasmodial activities of Nauclea latifolia. Asian J Med Sci. 2014;6(3):6-11. doi: 10.3126/ajms.v6i3.11361.

29. Fidock DA, Rosenthal PJ, Croft SL, Brun R, Nwaka S. Antimalarial drug discovery: efficacy models for compound screening. Nat Rev Drug Discov. 2004;3(6):509-20. doi: 10.1038/nrd1416.

30. Alli LA, Adesokan AA, Salawu OA, Akanji MA, Tijani AY. Anti-plasmodial activity of aqueous root extract of Acacia nilotica. Afr J Biochem Res. 2011;5(7):214-19.

31. Loomis TA, Hayes AW. Loomis's essentials of toxicology. 4th ed. California: Academic Press; 1996:208-45.

32. Chandel S, Bagai U, Semwal RB, Semwal DK. 
Antiplasmodial activity of aqueous extract of Berberis aristata roots against Plasmodium berghei-infected BALB/c mice. Pharm Biol. 2015;53(12):1735-40. doi: 10.3109/13880209.2015.1005750.

33. Ivanova IP, Trofimova SV, Piskarev IM. Evaluation of prooxidant properties of ascorbic acid. Biophysics. 2013;58(4):453-6. doi: 10.1134/s0006350913040076.

34. Chakraborthy A, Ramani P, Sherlin HJ, Premkumar $\mathrm{P}$, Natesan A. Antioxidant and pro-oxidant activity of vitamin $\mathrm{C}$ in oral environment. Indian J Dent Res.
2014;25(4):499-504. doi: 10.4103/0970-9290.142547.

35. Nafiu MO, Abdulsalam TA, Akanji MA. Phytochemical analysis and antimalarial activity aqueous extract of Lecaniodiscus cupanioides root. J Trop Med. 2013;2013:605393. doi: 10.1155/2013/605393.

36. Bitew H, Mammo W, Hymete A, Yeshak MY. Antimalarial activity of acetylenic thiophenes from Echinops hoehnelii Schweinf. Molecules. 2017;22(11). doi: 10.3390/ molecules22111965. 